\title{
اضطراب الوسواس القهري لدى الاطفال الابينين باضطراب طيف التوحد
}

\author{
! \\ الباحث/ طارق أحمد عبد السلام محمود التتولي
}

$$
\text { اشراف }
$$

$$
\begin{aligned}
& \text { أ. د/ محمد حسين محمد سعد الدين الحسيني } \\
& \text { أستاذ علم النفس } \\
& \text { بكليت الآداب - جامعت المنصورة }
\end{aligned}
$$

$$
\begin{aligned}
& \text { المجلت العلميت لكليتت رياض الأطفال ـ جامعت المنصورة } \\
& \text { المجلد السادس ـ العدد الثانى }
\end{aligned}
$$

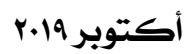




\section{اضطراب الوسواس القهري لدى الاطفال المصابين باضطراب طيف التوحد}

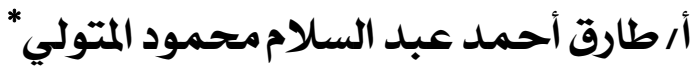

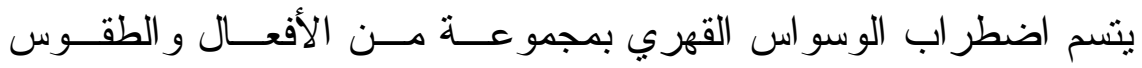

و الاندفاعات الحركية و التي يقوم بها الفرد بشكل تكر اري رغم عــدم أهميتهـــا و عدم عقلانيتها إلا أنها تأخذ هيئة الرغبة الجامحة للقيام بها، وذللك للتخلص من إلحاح الأفكار القهرية و التوتر و القلق الناتج عنها، ومن أكثر الأفعال و الطقــوس وله

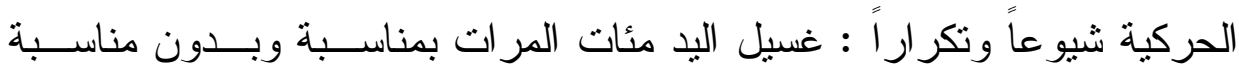

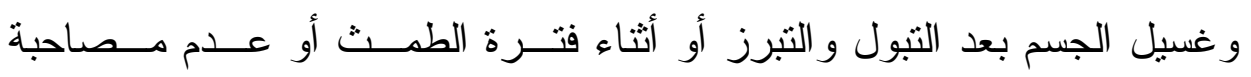
الآخرين أو إمساك كل شيء بورقة خوفاً من التلوث، وقد لا تتم هــذه الأفعــال

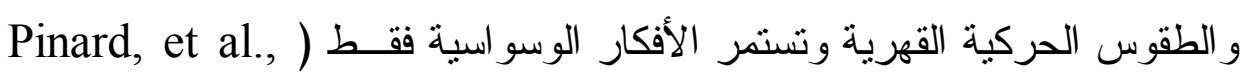
.(2004: 266

ويعتبر الوسو اس القهري احد اضطر ابات القلق العــصـابية الــذي يتميــز بوجود أفكار قهرية ملحة متكررة ، تقتحم تفكير الثخص وتسبطر عليه بحيــث

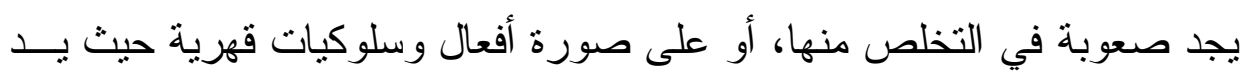
الثخص نفسه مضطر اً للقيام بها بالر غم من قناعة الثخص بتفاهـــة أو ســذاجة

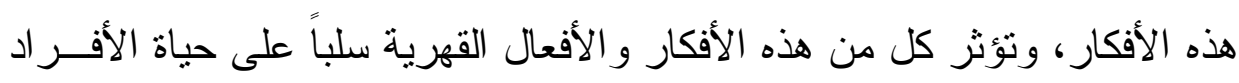

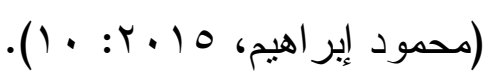

\begin{tabular}{ll} 
& \\
\hline "احث دكتوراه. *
\end{tabular}




\section{مفهوم الوسواس القهري: Obsessive Compulsive}

تعرفه الجمعية الأمريكية للطب النفسي في الدليل التشخيصي و الأخصائي

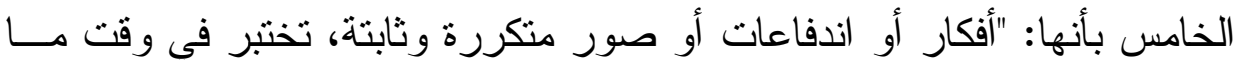

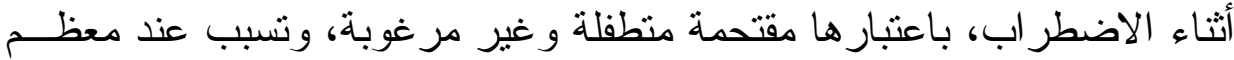

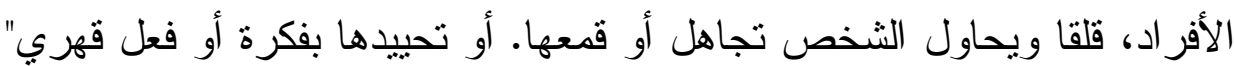

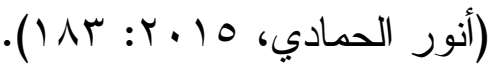
ويعرف بأنه: "عبارة عن أفكار ثابتة أو نزعات أو خيالات يخبرها الفــرد

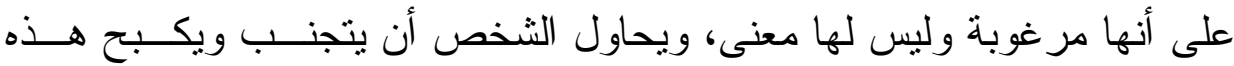

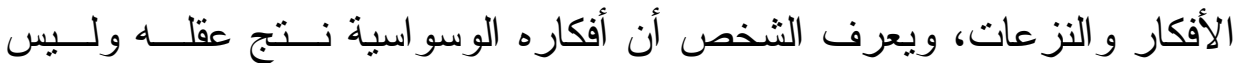

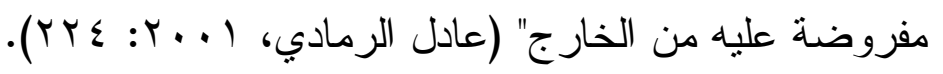

ويعرف ايضا على انه: "أفعال يضطر المريض لفعلها ليقلل من إحسساسه

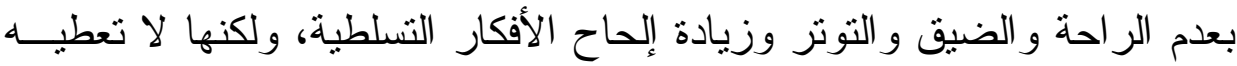

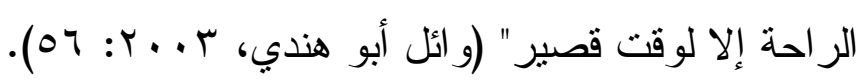

وعرفه زهران بأن الوسواس هو فكر متسلط و القهر هو ســلوك جبـري يظهر بتكر ار وقوة لدى المريض ويستحوذ عليه ويفرض نفسه عليه و لا بستطيع

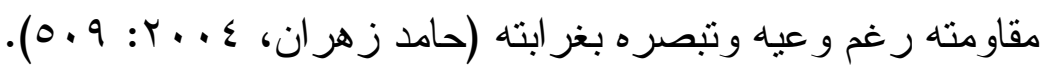
وتعرفه "آمال قطنية" بأنه: أفكار متكررة تتذخل فـي الـسلوك الـسوي وتعطله، فتتـل ذهن المريض ويشعر بنو ازع تبدو غريبة عنه، ويضطر للقيــام

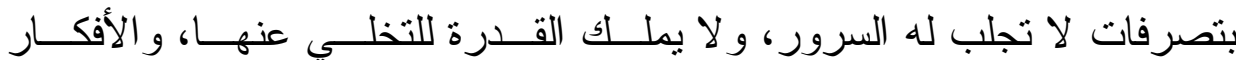

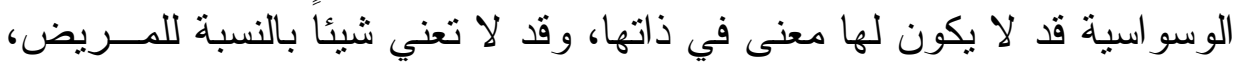

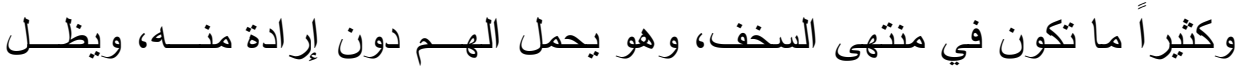


يتأمل ويفكر ، وكأن الأمر يتعلق بالحياة أو الموت بالنسبة له. من ناحية أخــرى

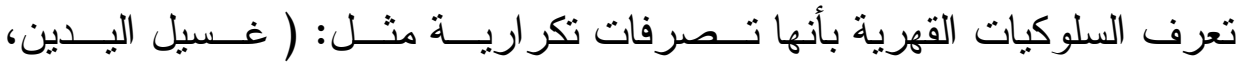

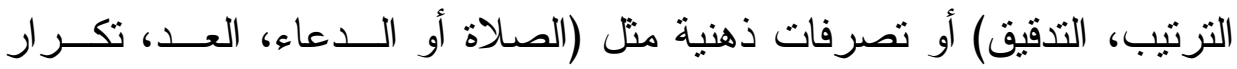
كلمات بين المريض ونفسه) و التي يشعر المريض بأنه مدفوع للقيام بها تجاوبـاً

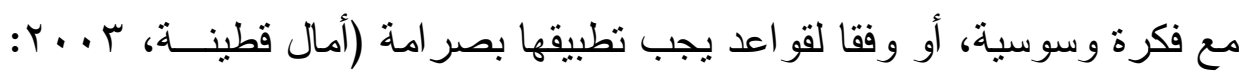

وعرفه "نعيم الرفاعي" بأنه أفكار أو دو افع شعورية تتسلط عالــى الفــرد

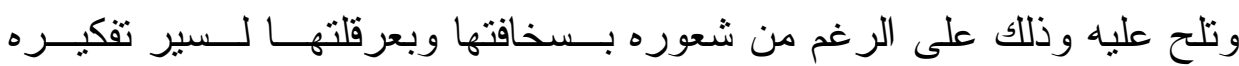

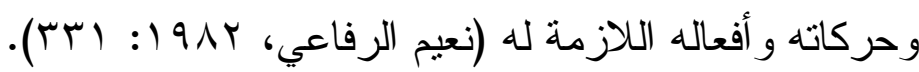

ومما سبق يرى "الباحث" ان الوساس القهري لة انثكال متعـددة، فيوجـــ

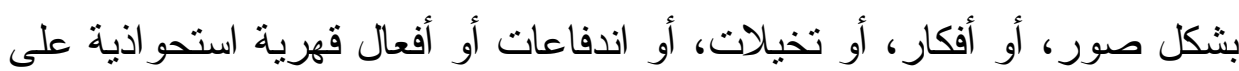

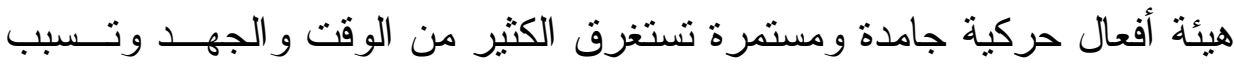
المزيد من الأسى و القلق النفسي.

ويحاول المريض جاهداً تخفيف حدة القلق و التوتر عــن طريــق القيــام بالأفعال القهرية، ومن ثم يذور في دائرة مفرغة من القلق و التوتر، لا يـستطيع

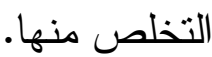

\section{معدلات انتشار الوسواس القهري:}

يعتبر الوسو اس القهري ومنذ زمن بعيد أحد الأمسر اض النـادرة، لكـن

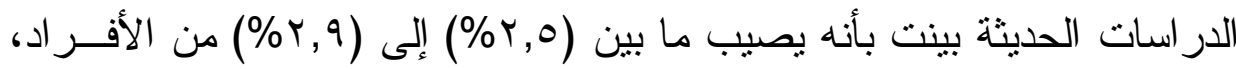

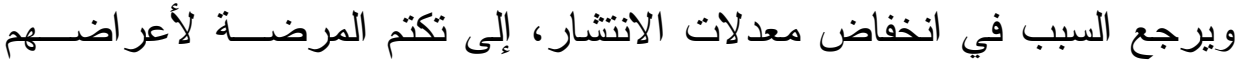


خشية الوصمة وغر ابة الأفكـار التــي نــر اودهم فحسبب دراســة Van der .(Linden, M., Ceschi, G., 2008: 119) ولكن على الرغم من تقدير انتشار اضطر اب الوسوس القهري على مدى

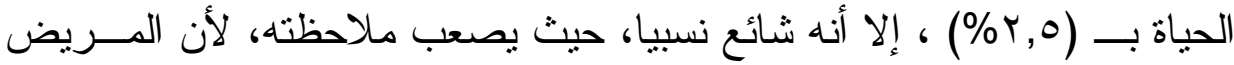

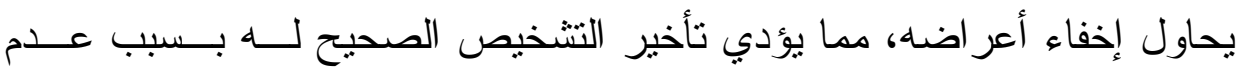

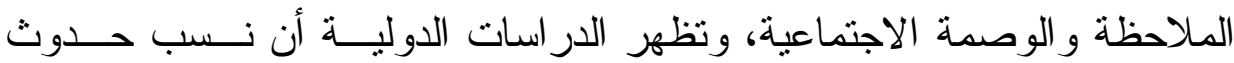

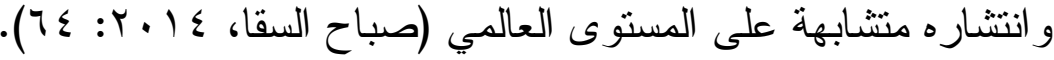
وقد يعاني مريض الوسو اس القهري بواحد أو أكثر من فكرة وسواسـية،

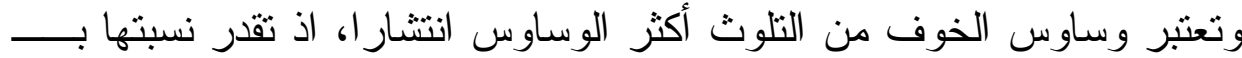

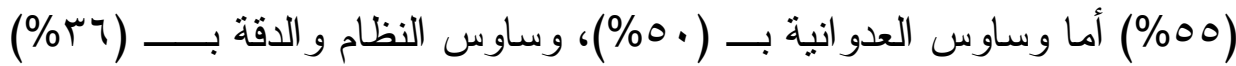

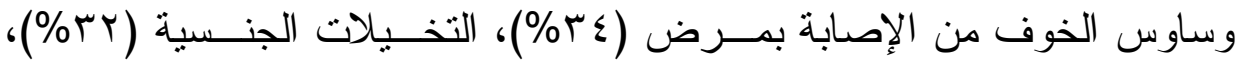

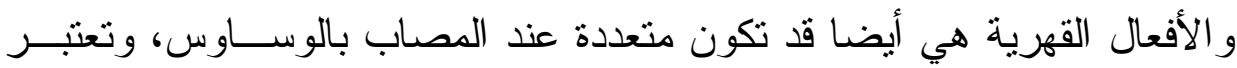

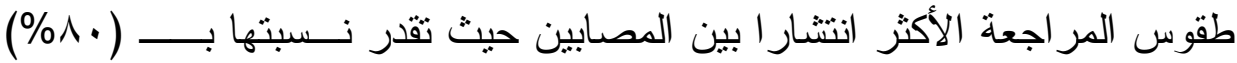

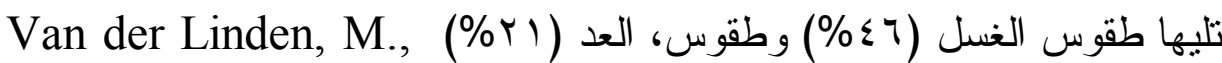
.(Ceschi, G., 2008: 119) ويظهر عند الذكور ما بين (7) و (10)، أما عند الإنــاث فيظهـر بـين .(O’Leary, E., 2005: 20) (rq: : • )

وظهور اضطر اب الوسواس القهري يكون بشكل تدريجي، غير أنه توجد

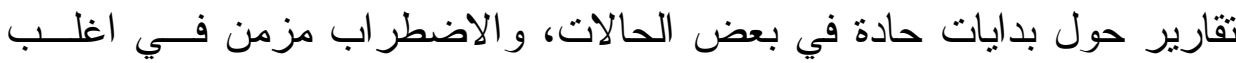

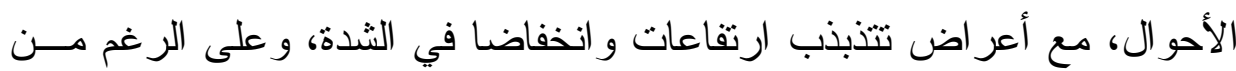

r المجلد السادس


ذللك فقد لوحظت نوبات ودور ات من التدهور لدى حوالي (•(1\%) من المرضى

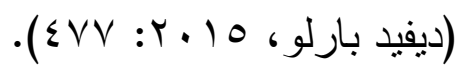

\section{المعايير التشخيصية للوسواس القهري تبعا (DSM5):}

قبل النطرق إلى المعايير التشخيصية، لابد من الإثشارة إلى أنه في الــليل

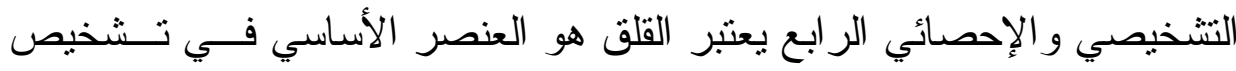

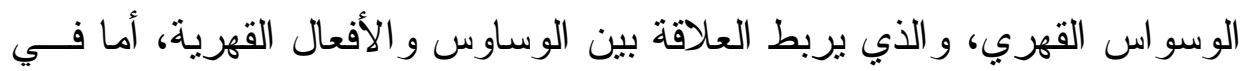

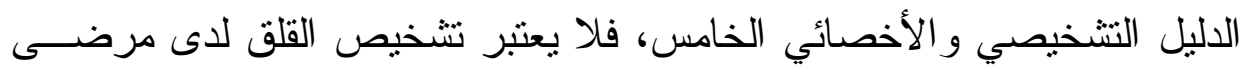
الوسو اس القهري ضروريا، لذا فقد نم إلغاء اضطر اب الوسو اس القهري من فئة

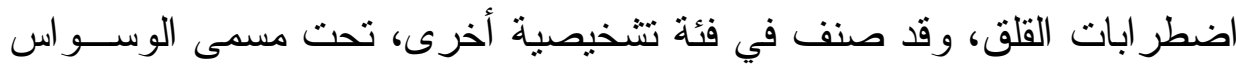

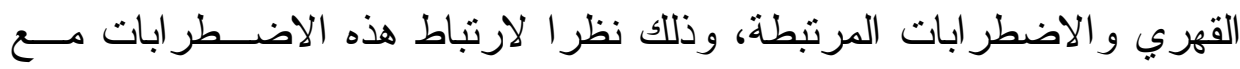
بعضها من حيث مدى الصادقات التشخيصية (أنور الحمادي، 10 • ب: 10 (1). عو امل اضطر اب الوسواس القهري: لا يوجد عامل و احد ودقيق لحدوث الوسواس القهري لكـن؛ بــل هنــاك بعض العو امل التي تؤدي إلى حدوثه ومنها ما يلي:

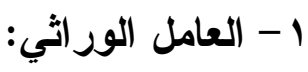

يلعب العامل الور اثي دوراً هاماً في نشأة الوسواس القهري، فقد أثنــارت

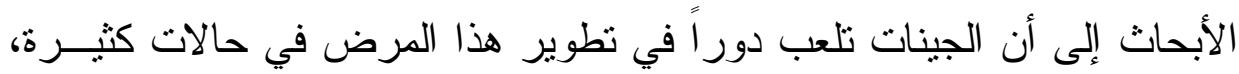

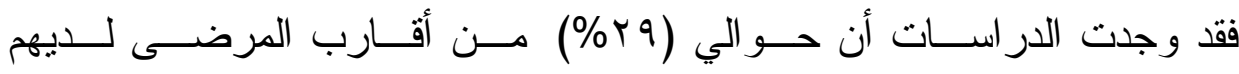

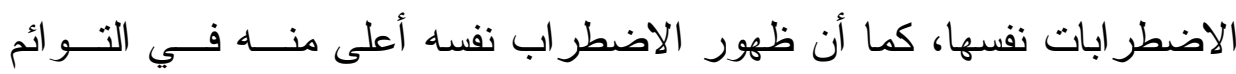

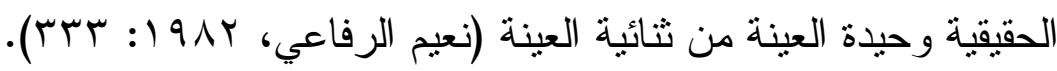




\section{r - العامل الفسيولوجي الخاص بالجهاز العصبي:}

هناك أسباب فسيولوجية خاصة بالجهـاز العـصبي وكهربائيــة نـشاط

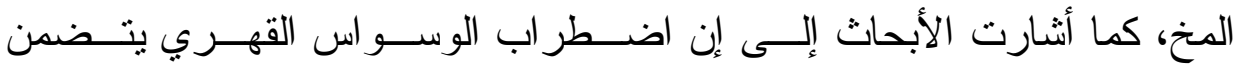

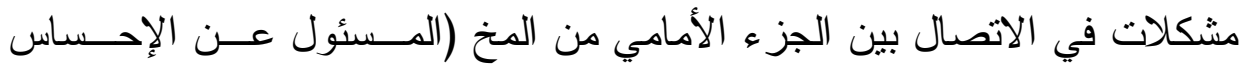

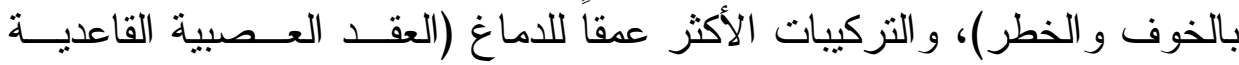

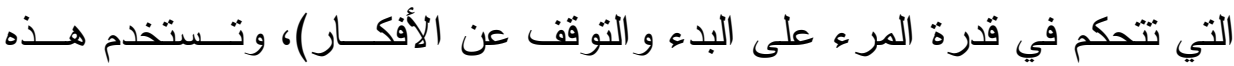

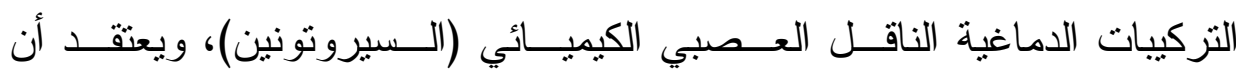
اضطر اب الوسو اس القهري برتبط بنقص فـي مسستوى الـسيروتونين (نعـيم

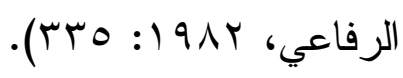

\section{r- العامل الوراثي متحدا مع البيئي:}

ان تأثثير ات أحد الو الدين أو كلاهما المنظمة ذات المنل العليــا والــضـمير

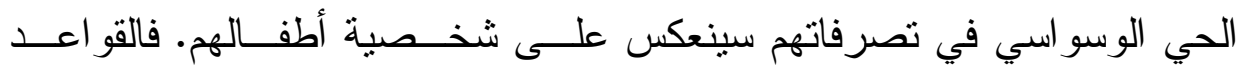

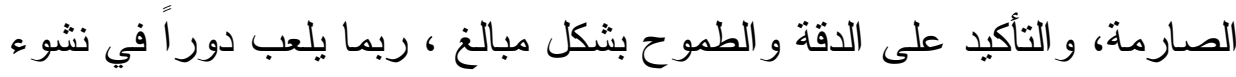
اضطر اب الوسواس القهري (Myhr. G,, et al., 2004: 447). وذكرت "رمزية غريب" في در اسة أن للوسواس القهري عدة أسباب هـي

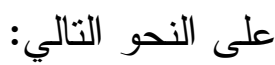
م الأمر اض المعدية الخطيرة أو المزمنة.

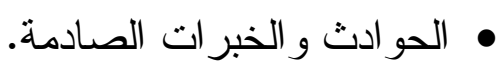

مالصر اع بين عناصر الخير و الثر و الرغبات اللاثتعورية المتصارعة. • التعرض للإحباط المستمر في المجتمع. 


$$
\text { ه الخف و عدم الثقة في النفس و الكتب. }
$$

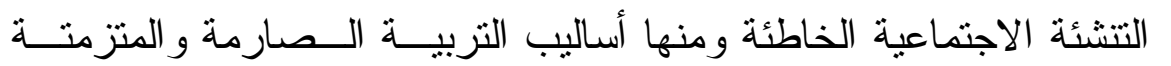

$$
\text { و المتسلطة و القامعة. }
$$

$$
\text { • الثعور بالإثم وتأنيب الضمير. }
$$

• تقليد سلوك الو الدين أو الكبار المصابين بالوسو اس القهري.

$$
\begin{aligned}
& \text { • وجود بؤرة كهربائية نشطة في لحاء الدفاع تسبب دو ائر كهربائية تـؤدي } \\
& \text { إلى نفس الفكرة أو نفس السلوك (رمزية غريب، ـ99 } 99 \text { 1: } 11 \text { (0). } \\
& \text { أنواع الوساوس القهرية: }
\end{aligned}
$$

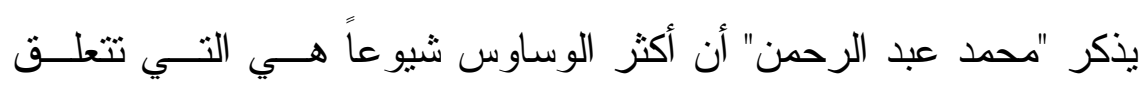

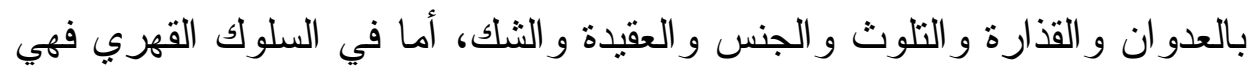

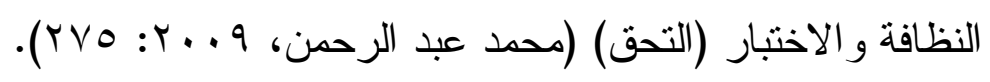

و اتفق معه (أحمد عكانشة) في أن أكثر الوساوس شــيو عاً هـي الغـسيل

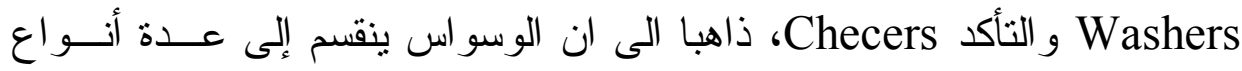

$$
\text { تتمنل في الأتي: }
$$

1- الأفكار Ideas.

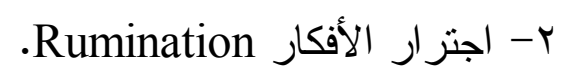

$$
\text { Image r الصور }
$$

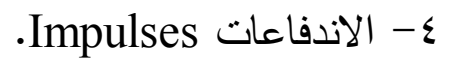

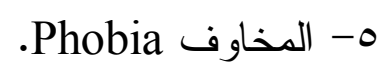

r المجلد السادس




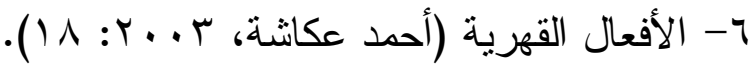 \\ النظريات المفسرة للوسواس القهري:}

توجد عدة نظريات تفسر الإصابة باضطر اب الوسواس القهـري و التــي

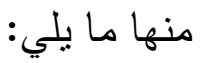

1 - نظرية التحليل النفسي:

برى أصحاب هذه النظرية أن اضطر اب الوسواس القهري يحدث نتيجــة

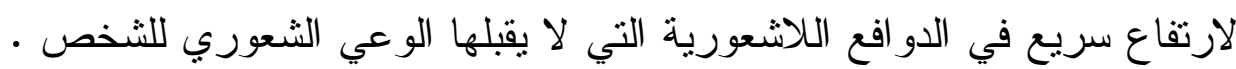

ويحدث نتيجة لسبب معجل (مفجر) للإصابة في حياة الثخص التي قد تحتــوي

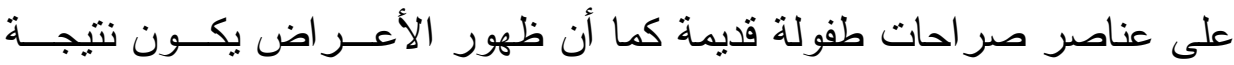

لنكوص الثخصية لمرحلة سابقة ـوتفسر الدورة الوسواسية القهرية، وخاصـــة

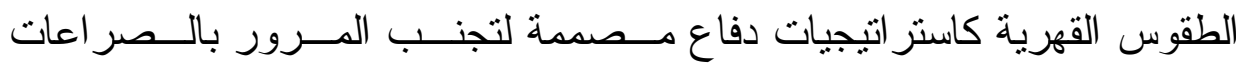
و الدو افع اللاشعورية غير المرغوبة. فينتج عنها الثشعور بالإثم وعقــة الـــنب

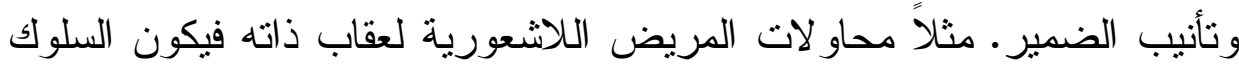
القهري بمثابة تكفير رمزي وإراحة للضمير • فيمكن أن يكون غـسيل الأيسـدي

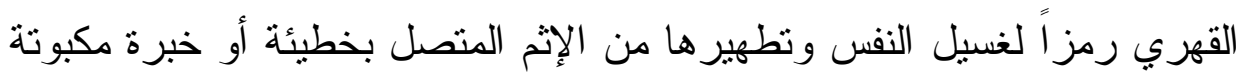

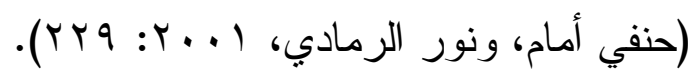
ويحدث تثييت في المرحلة الثرجية، نتيجة للأخطاء المرتبطة بالتـدريب

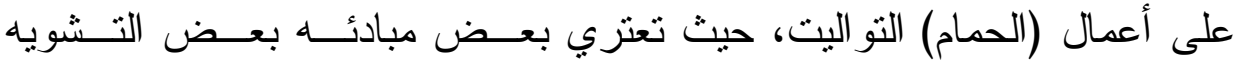

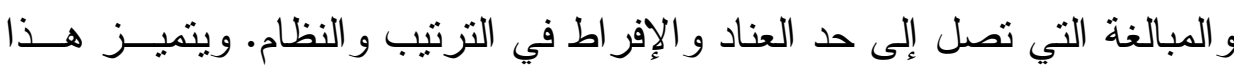

المجلد السادس


الننط بخصائص شخصية هي الترتيب أو المحافظة على النظام و البخل و العنــاد

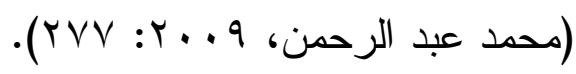

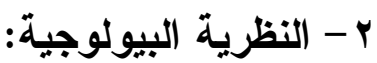

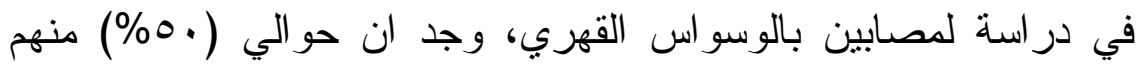
لايهز تقلص لا إر ادي في عضلات الوجه وحركات جسيمة لا ار ادية منل الغمز بالعينين، وتطيب الوجه و الجبين. ومن الاضطر ابات العصبية التي تحدث بشكل Sydenhams " متكرر لاى مرضى الوسو اس ما يعرف بمرض خورياسيندهام chorea"، وهو اختلال عصبي يتميز باضطر ابات نتشنجية سريعة وعنيفة في

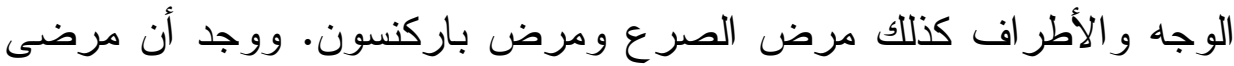
الوسواس القهري لديهم معدل مرتفع للتمنيل الغذائي للجلوكوز في الفص

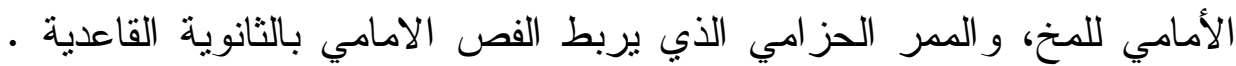

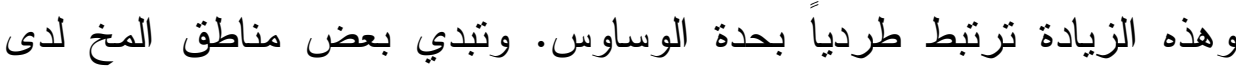
المرضى أنثطة شاذة نتيجة لنقص السيروتونين حيث وجد أن أكثر العقاقير فعالية، تزيد كمية اليروتونين في الهخ كذلك وجد أن ليدهم ارتفاع هرمون

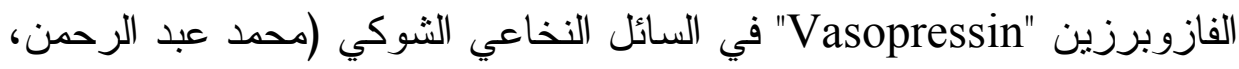
.( rVq: $r \cdot \cdots 9$

وان أثنكال النسلط والقهر التي توجد لدى الأطفال قبل نضجهم تؤيد

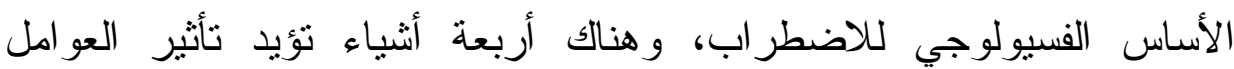

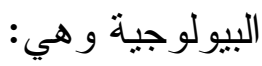
1. الإمر اض النيورولوجية المصاحبة للاضطر اب (كالصرع و اضطراب

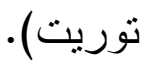




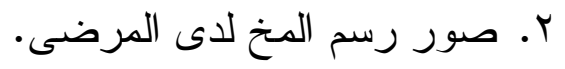

$$
\begin{aligned}
& \text { r. السلوك القهري و العناد لدى الأطفال. }
\end{aligned}
$$

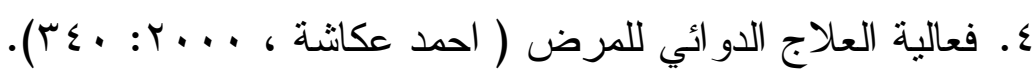

$$
\begin{aligned}
& \text { ب- النظرية السلوكية: }
\end{aligned}
$$

تزى أن السلوك المرضى يتم تعلمه من خلال البيئة. ويحدث الوســواس

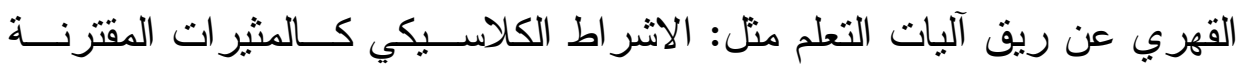

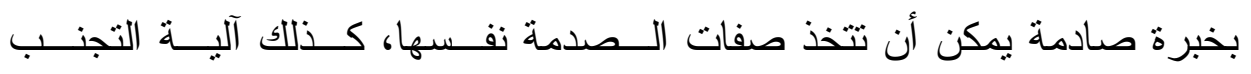
و الهروب، فالإنسان لا يحب الخبرات التي تتميز بــالقلق ويتجنبهــا، فالــسلوك ك.

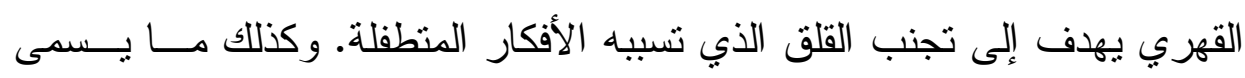

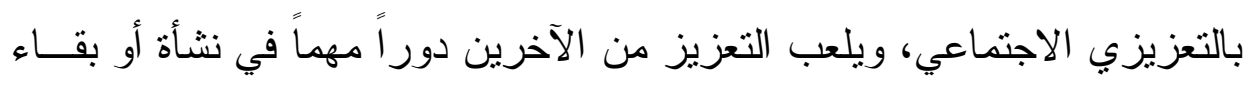

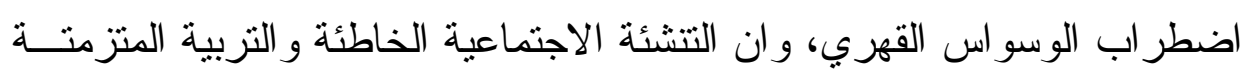
الصارمة المتسلطة الآمرة الناهية و القسوة و العقاب و التذريب الخــاطئ المت شُدد على النظافة و الإخر اج في الطفولة كلها أسباب بيئية تتفاعل مع الطرق السلوكية

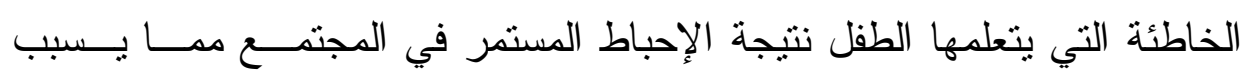

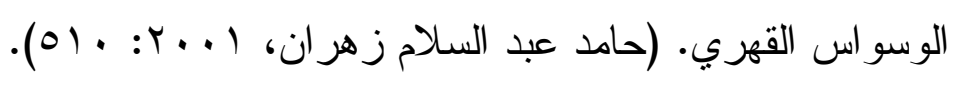

\section{ع - النظرية الاجتماعية:}

يرى أصحاب نظرية التعلم الاجتماعي أو التعلم بــالنموذج أن الأطفــال

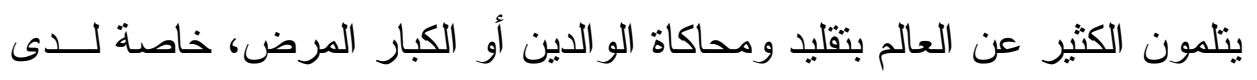

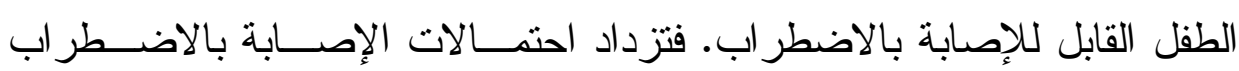

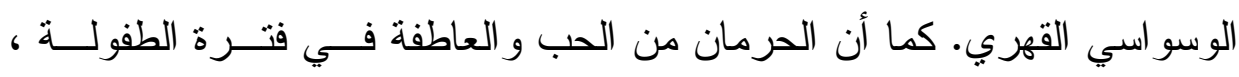


و أنو اعا معينة من البيئات الاجتماعية قد تؤدي إلى الإصابة بالوسو اس القهـري

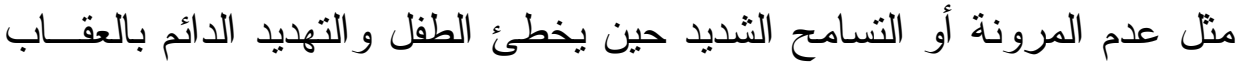
ورسم روتين مألوف لا يمكن الخروج عليه للأطفال، كل هذه الأساليب التربوية

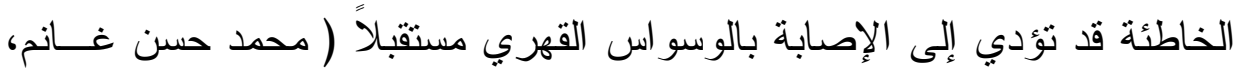
(T): $:$. . .

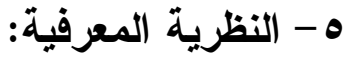

يرى أصحاب هذه المدرسة أن المصابين بالوسواس يفسرون الإثــارات

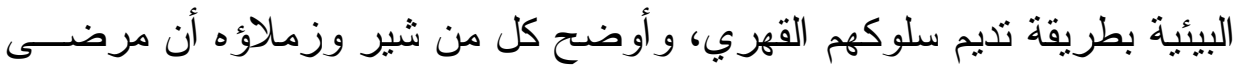

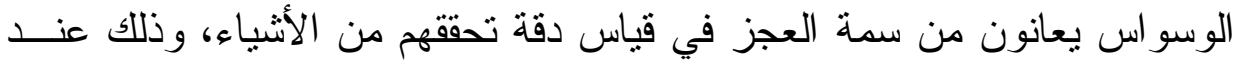

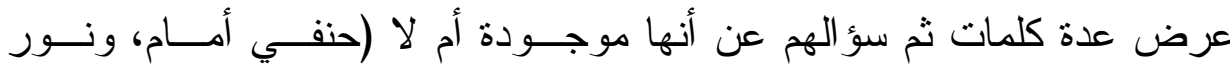

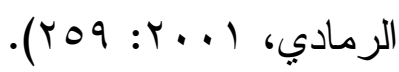

ويذكر (ارون بيك) ان المحتوى الفكري للوساوس يتعلق بــفة عامــة

بخطر بعيد يظهر في هيئة شك أو حبطة ، فالمريض قد أدى عملاً ما ضــرورياً لتأمين سلامته (أطفأ فرن الغاز على سبيل المثال) أو أنه سيتمكن من أداء عهـلـل

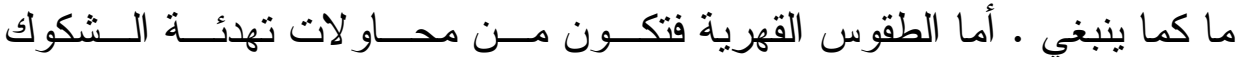

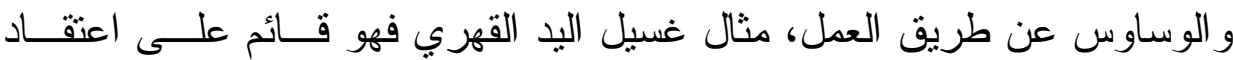

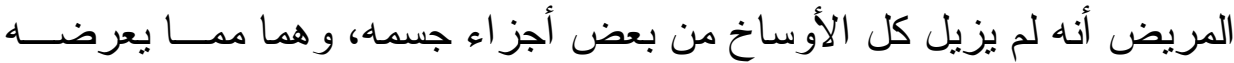

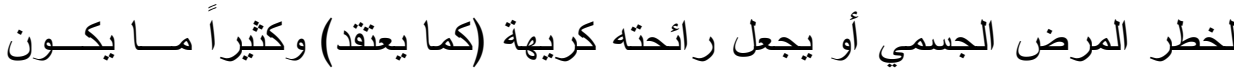
هنالك ثالوث متلازم هو الرهاب (الخوف المرضى)، الوسواس، الفعل القهـري. كحالة المريض الذي كان يخشى الإصابة بالاثتعاع فيتجنب (رهاب) كل الأثياء

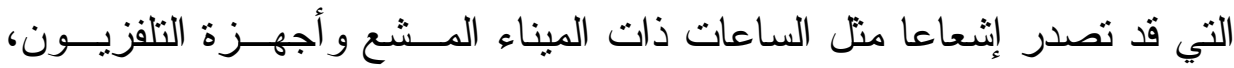


وحين تضطره الظروف إلى لمس شيء منها يظــلـل يـــر اوده احتمــال التلـــوث (وسو اس) مما يحمله على اخذ حمات متكررة طويلة كي يزيل المــادة المــشعة التي يتوهمها (فعل قهري) يمكن القول ان المحتوى الفكري لمريض الوســواس هو الحذر و الثك أما الفعل القهري فهو أمر ذاتي لأداء فعل محدد لدفع خطر ما

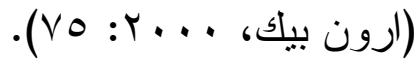

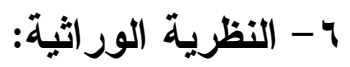

قد بينت در اسـات عديدة وجود تــأثنير و اضـــح للور اثــة فــي الإصـــابة

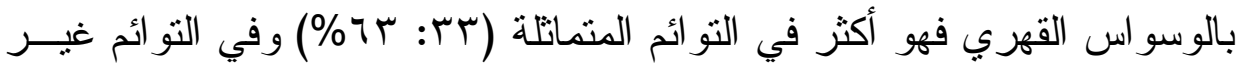
المتماثلة (V) وتكون العو امل الور اثية أكثر وضوحاً في الحالات التي يبدأ فيها المرض قبل سن الر ابعة عشر • ونسبة الإصـابة في أفر اد عائلة المريض أعلـى من أفر اد المجتمع حيث وصلت (0٪\%) في الأقارب من الدرجة الأولى مقارنة ب (1: r\%) من أفر اد المجتمع كما أن نسبة الاضطر اب فـي أبــاء و أمهــات

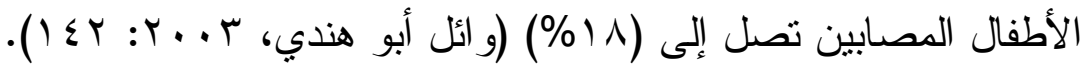

\section{اضطر اب طيف التوحد: Autism spectrum disorder}

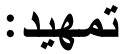

ان أول من قدم هذا الاضطر اب هو الطبيب النفسي السويـسري ايجــن بلولر "Eugen Bleuler" عام (1911 ) حيث اســتخدم التوحـــ ليــصف بـــ الأشخاص المنعزلين عن العالم الخارجي و المنسحبين عن الحيــاة الاجتماعيــة (عادل شبيب، 1 . . r: ؛ 1). 


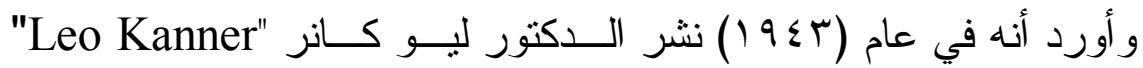
ورقته المشهورة عن التوحد ليكون بذلك أول من ذكره كاضطر اب محسـد فئسي العصر الحديث. وفي عام (ع 9 ()) نشر الدكتور "هانز اسبرجر" من فيينا ورقة

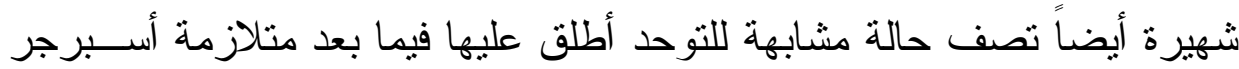
Asperger Syndrome لثر ح هذا الاضطر اب المعقد (Carr, E and D, M., 1985:111). وفي عام (ع 97 (1) اكتثف برنارد ريملاند "Bernard Rimland" أدلـــة

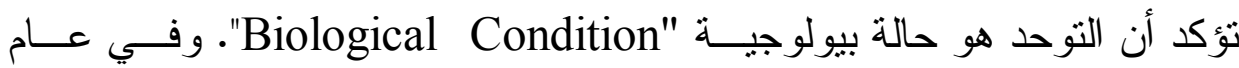

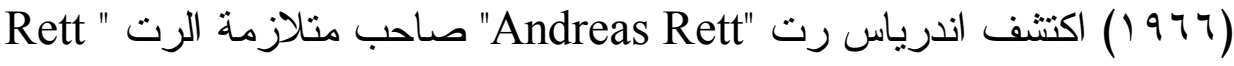
Wing, ) "Clark, N.," دليلاً آخر يؤكد أن التوحد حالة بيولو لرجية "Syndrome .(L., 1996: 301

وفي عام (9VV Ilustin" عثر كل من سوزان فلوستين، ومايكل روتر "Susan Flostein, Michael بأن هذا دليل علي احتمالية وجود عامل جيني يقف خلف الإصابة بالتوحد. وفي

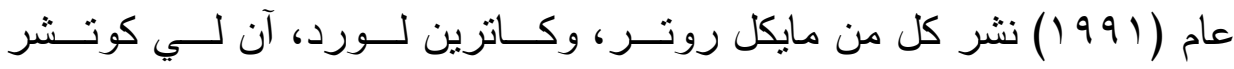
Catherine Lord, Michael Rutter, Ann Le Couteur"' لتشخيص التوحـ "Wakefield, A., )" Autism Diagnostic Interview .$(1998: 351$

وفي عام (1999) أصدرت منظمة الصحة العالميــة " World Health

"Organization

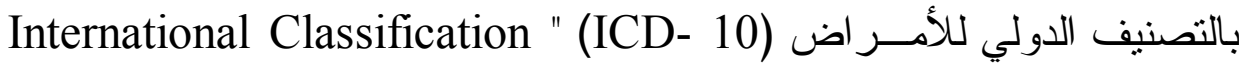


of Diseases" World Health Organization, ) "Developmental Disorders" .(1992: 198

\section{مفهوم اضطر اب طيف التوحد:}

يُعد الطبيب الامريكي كانر "Kanner" أول من وصف اضطر اب طيـف

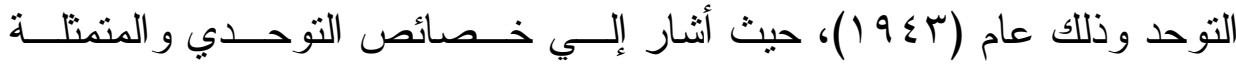
بالنقص الثديد في التواصل مع الآخرين، و الميل إلي المحافظة علــي الــروتين

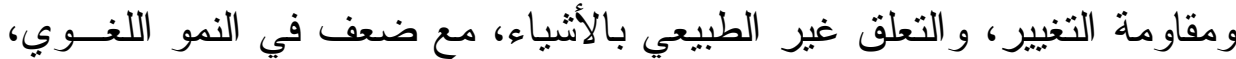
وضعف القدرة علي التخيل، و انشرط حدوث هذه الأعر اض خلال الثلاثين شهر

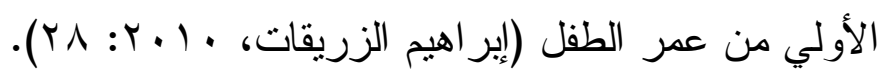

ويستخدم مصطلح اضطر اب التوحد للتعبير عـن فئـة ذوي اضــطر اب

التوحد التقليدي و المعروف لدي الغالبية باختلاف شدة الاضطر اب إذ يتر اوح مـــا

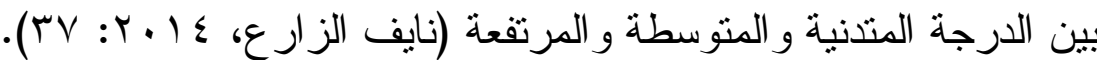
وتعرفة "الجمعية البريطانية الوطنيــة للأطفـــال التوحسـيين" علــي أنـــه

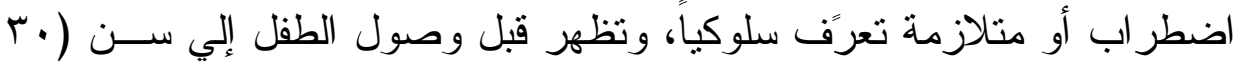

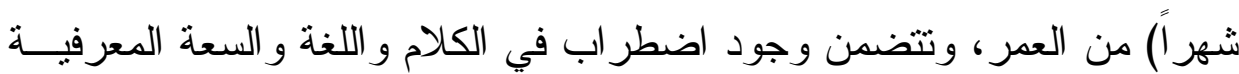
و الاستجابة الحسية و التعلق و الانتماء بالأثياء و الموضو عات و الأحداث. (فوزية

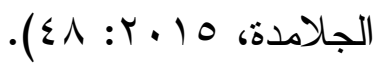

وعرفتة "الجمعية الأمريكية للتوحد" علي أنه إعاقة نمائية تطورية تظهـر في الثلاث سنو ات الأولي من العمر ، نتيجة للاضطر ابات العصبية التـي تــؤثر

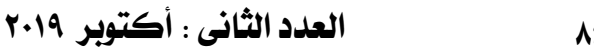


علي وظائف المخ و النمو الطبيعى و النشاط العقلي، وتتميز بقـصور التواصـلـ

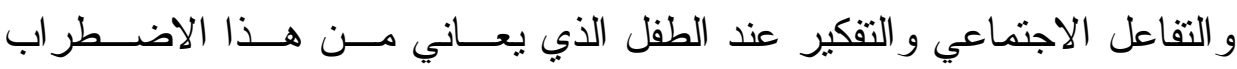

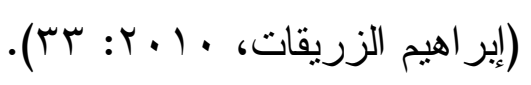

\section{النظريات و الفرضيات المفسرة للتوحد:}

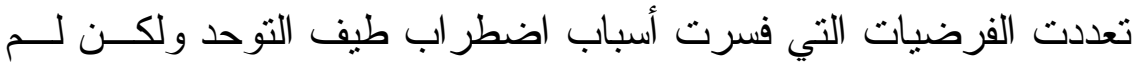

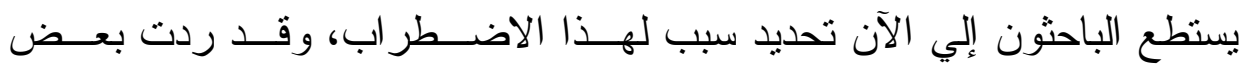

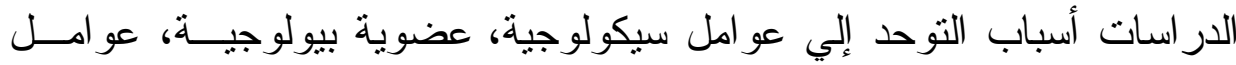

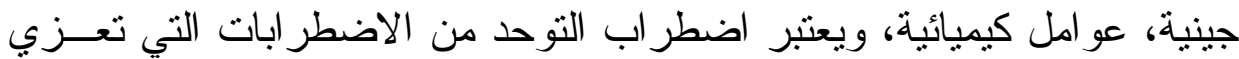

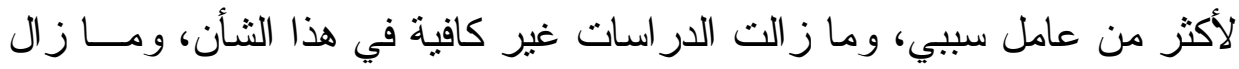
هنالك غموض حول سبب الاصابة بهذا الاضطر اب.

أولاً: الفرضية السيكولوجية (النفسية):

انشار كانر "Kanner" في أول تقرير له عن النوحد أن العامل المـسبب

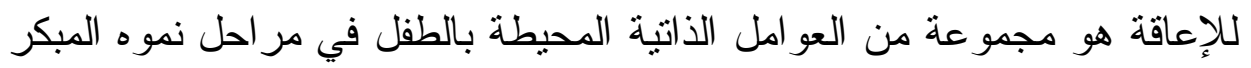

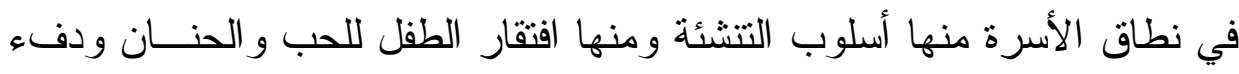

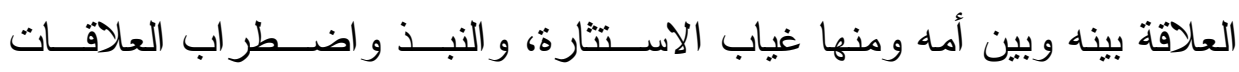

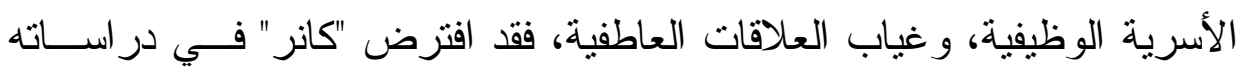

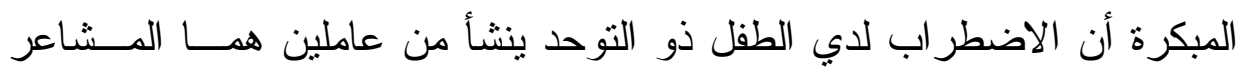

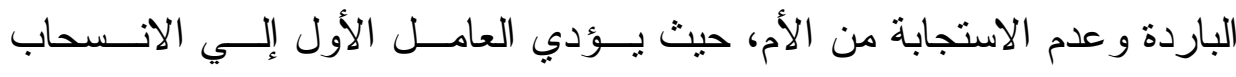

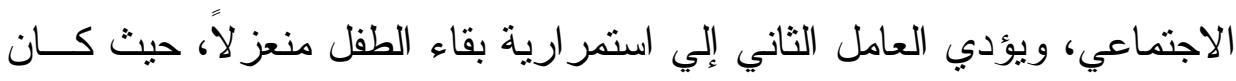

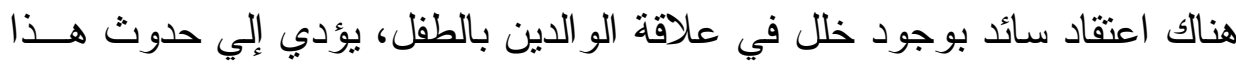

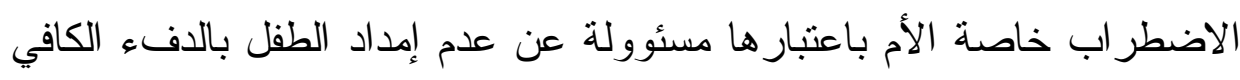


و الانفعال المناسب وذلك إلي الحد الذي وصف و الــدي الطفـلـل ذي اضـــر اب طيف التوحد بالو الدين ذوي المشاعر الباردة (ايهاب خليل، 9 . . ؟ ؟ ؟ ؛).

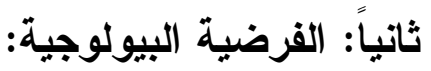

هناك من يفسر التوحد كنتيجة للعو امل البيولوجية، ومن أسباب تبني هـــا

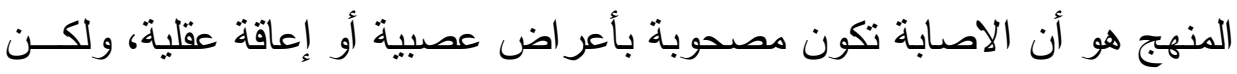
قد يكون هناك عدم قبول للفرضية البيولوجية عندما لا يوجد سبب طبي أو إعاقة

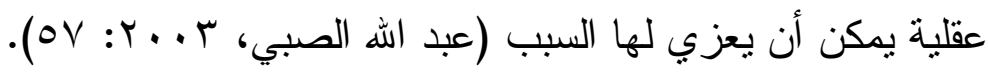

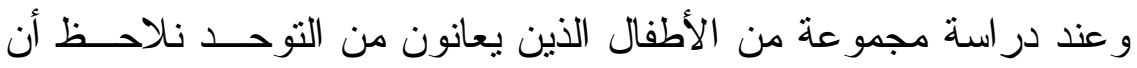

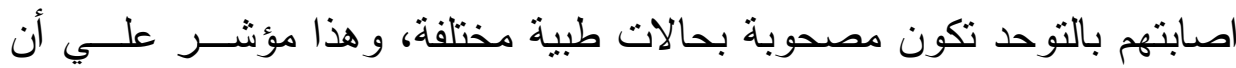

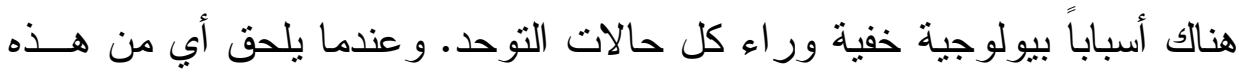

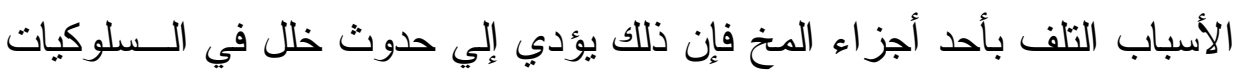

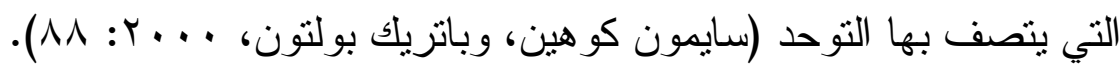

و هنالك من اثثار الي الاضطر ابات التي تحـــث قبــلـ الــول لادة بالنـسبة

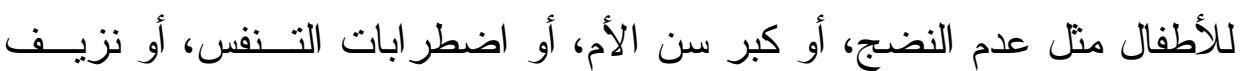

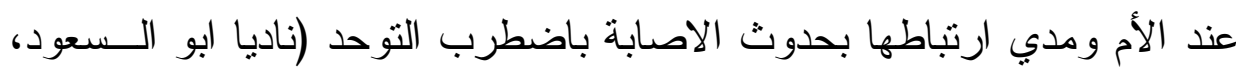
. ( 2 r....

وز اد الاهتمام بالتطعيمات وخاصة التطعـيم الثلاثتـي (MMR) و الــذي

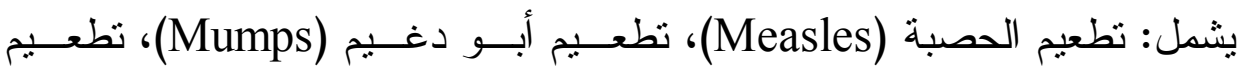

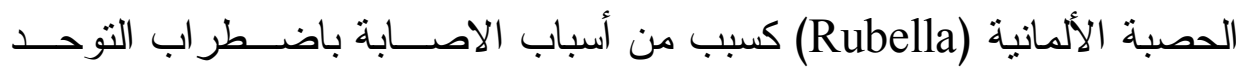
.(Wakefield, A., 1998: 367) 
ويؤكد الكثير من الباحثين أن الجهاز الهضمي لدي بعــ الأفــر اد ذوي

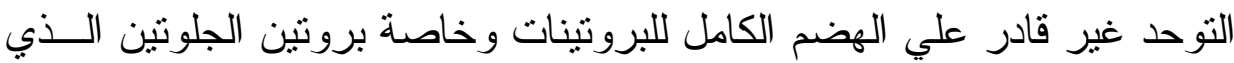
يوجد في الثوفان و الثعبير، وبروتين الكازيين الذي يوجد في الحليب ومـشُتقاته

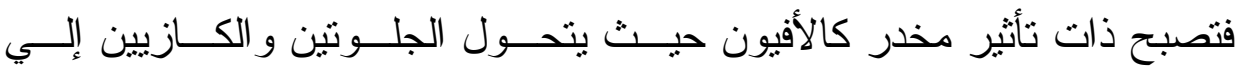
جلوتومورفين وهو ذو مفعول مخدر وهذا يؤدي إلي ظهور أعر اض وسلوكيات

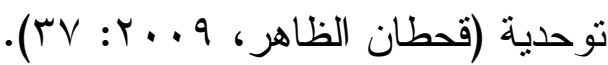

ويعتقد البعض أن سبب التوحد هو مشكلات تــصيب الجهــاز العـصبي

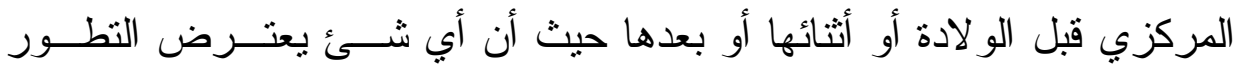

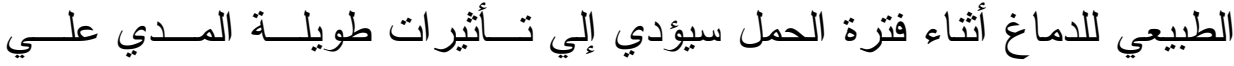

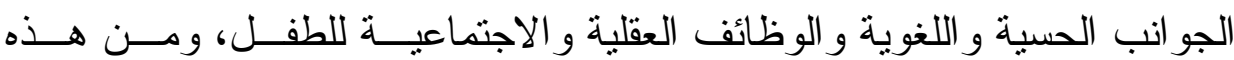

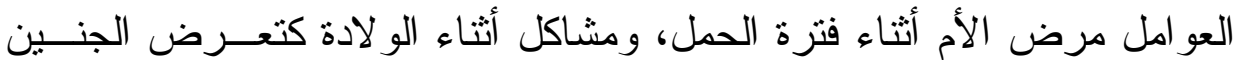
لنقص الأكسجين أو بعد الو لادة مبانرة (Bogdashina, O., 2006: 225).

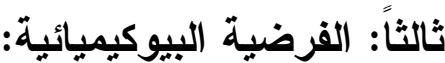
أجري بيفن "Piven" دراسة عن تأثثر العو امل الكيميائيــة فــي حسدوث

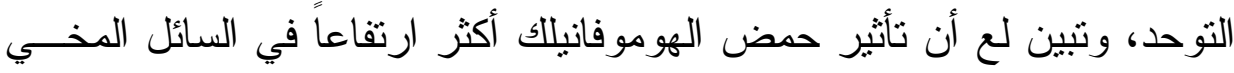

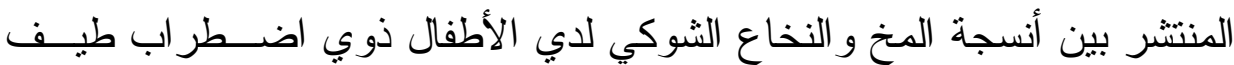

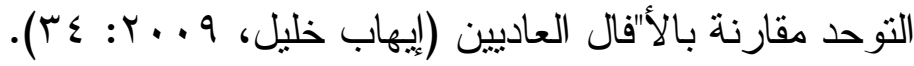
وتشير الفرضية البيوكيمائية إلي وجود مشكلة في النو اقل العصبية التـي

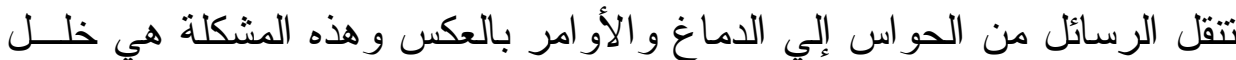

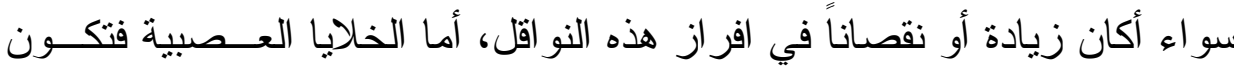
سليمة(Heward, L., 2003: 455). 
يؤكد الباحثّن علي دور العو امل العصبية في حدوث اضطر اب التوحـــ

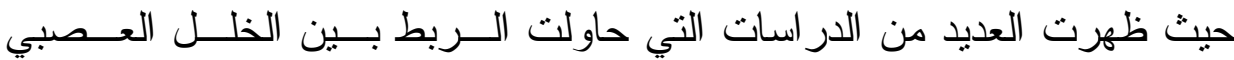

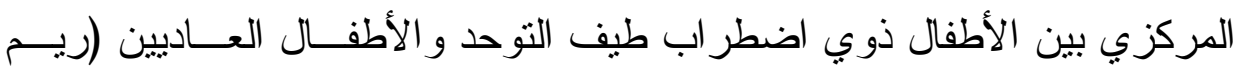

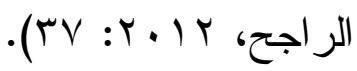

ويعتقد بعض الباحثين أن بعض أثنكال التوحد هي نتيجة لأذي في الدماغ

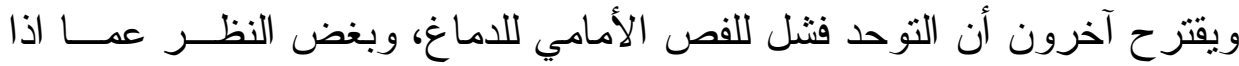
كان للتوحد أساس جيني (Smith, D., 2001: 506). وقد وجد بأن التخطيط الكهربائي للاماغ (E.E.G) في حسالات التوحسد

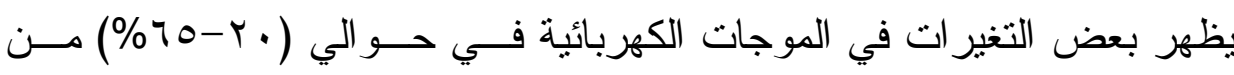
الحالات. وظهور حالات نوبات الصرع مع تقدم عمر الطفل التوحدي وقربه من

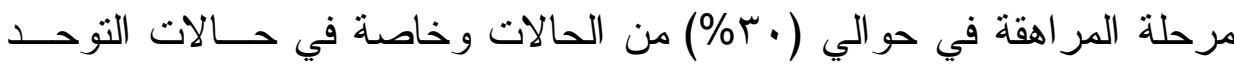

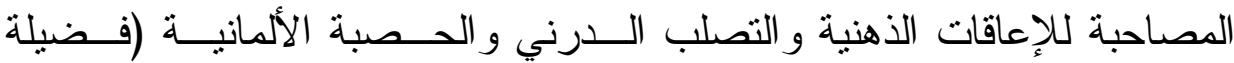
الر اوي، وآمال حماد، 999 (1: 09 09 ).

وفي تقارير ريملاند "Rimland" تبين وجود خلل و اصــابة فــي نـسيج

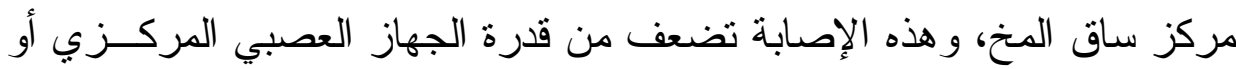
مخ الجنين علي الاستجابة للمثير ات الخارجية وحساسيته لها، ولقد وجد جيلبرج

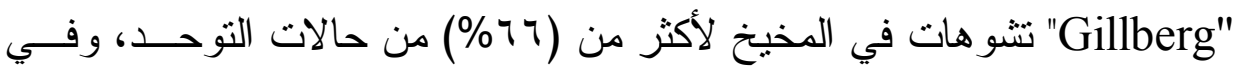

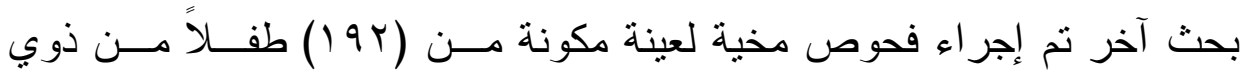

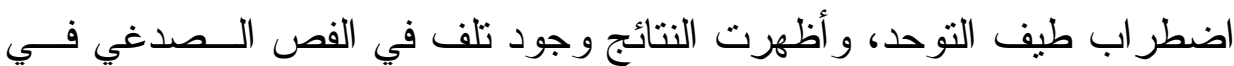


(Y9) حالة من هذة الحالات وهذا الفص توجد عليه مر اكـز التفــاهم و التفاعـلـل

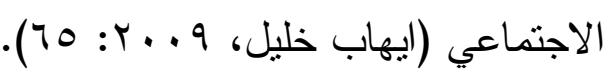

خامساً: الفرضية الجينية الور اثية:

أثنارت بعض الدراسات إلي أن المكون الور اثي لــه دور فــي حسدوث

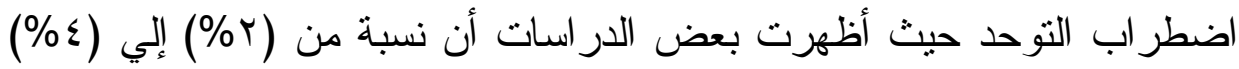

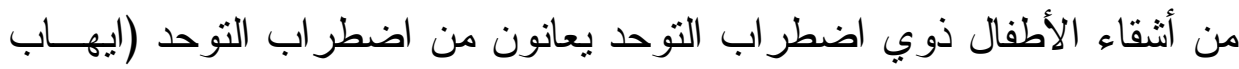

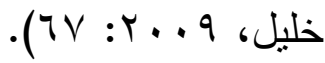
و أوضح كلارك "Clark" أن نسبة حدوث التوحد بــين الأثــقاء التــوائم

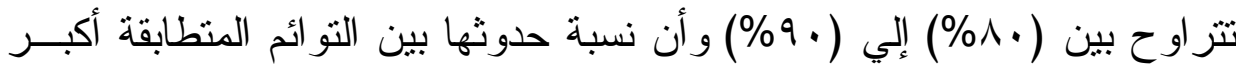
بكثبر من نسبة حدوثها بين النوائم غير المتطابقة مما يشير إلي أن للتوحد أساساً

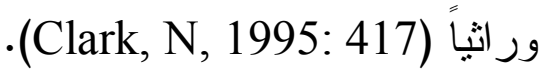

كما تبين أن حوالي (•^\%\%) من الأطفال ذوي اضطر اب التوحد الــذكور

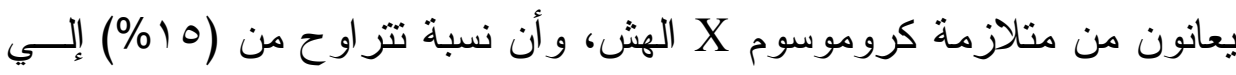

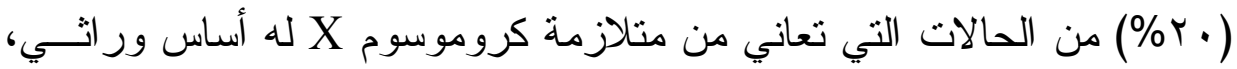

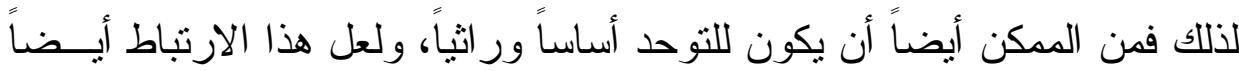

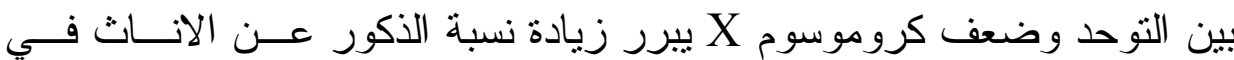

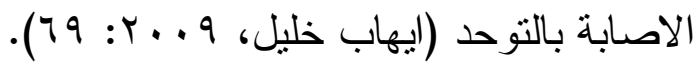
سادساً: نظرية العقل: لوحظ أن الأفر اد الذين يعانون من التوحد يجــدون صــوبة فـي فهـم الحالات العقلية للآخرين، ومشاعر هم و أفكار هم وعدم قدرتهم علي التتبؤ إضافة لإنة 
إلي إعاقة في التفاعلات الاجتماعية و التو اصلية و التخيلية وذللك نتيجة عدم نـــو الأفكار لديهم (Bogdashina, O., 2006: 228).

Obsessive الوسواس القهري واضطراب التوحد Compulsive Disorder, Autism spectrum disorder

يعد اضطر اب الوسواس القهري اضطر اباً نفسياً يتــصف بوجــود فكـــار

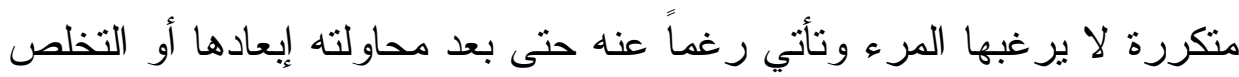

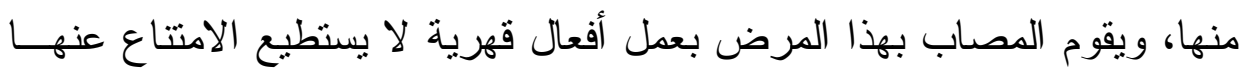

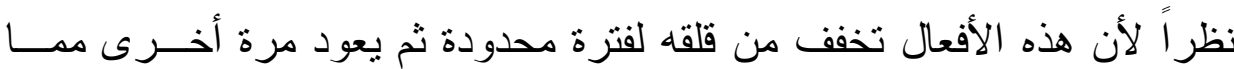

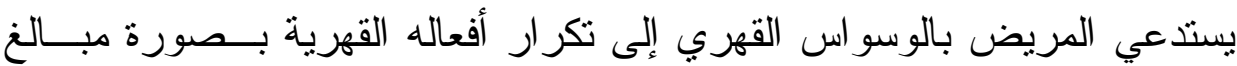
فيها.

وقد لوحظ أن بعض المصابين بالوسو اس القهري يعانون معانــاة نفـسية

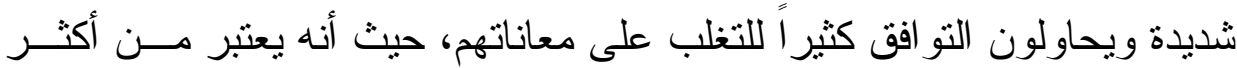

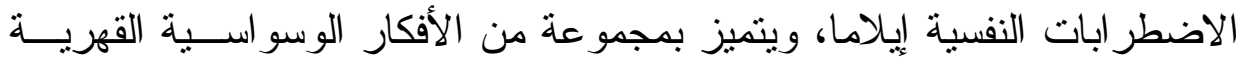

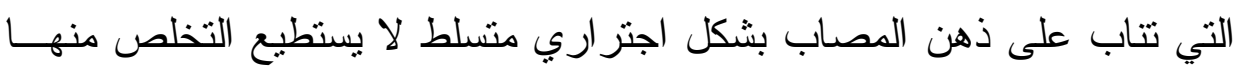
رغم محاو لاته المتكررة لمقاومة هذه الأفكار و التخلص منها دون فائدة، وتصبح

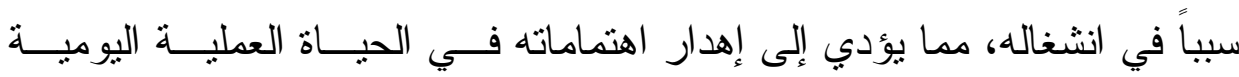
.(Greisberg, S., 2005: 265)

ويتميز اضطر اب الوسواس القهري بمجموعة مــن الأفعـال و الطقــوس

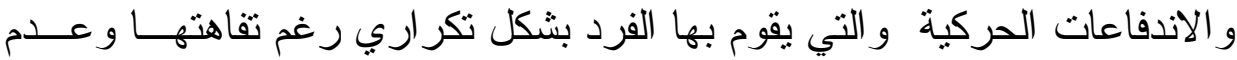

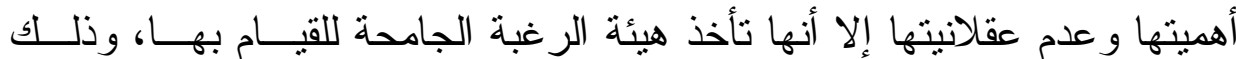

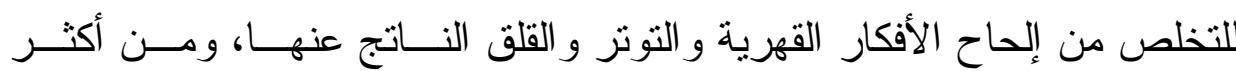


الأفعال و الطقوس الحركية شيو عاً وتكر اراً عند مضطربي طيف التوحــد هـز

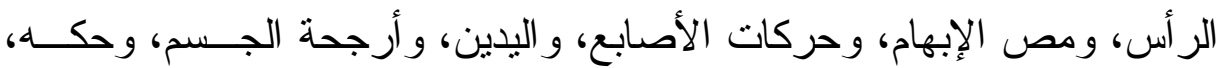
و التلويح باليد، ولف الثعر ، وهز الرجلين، وال تربيت على الوجـه، و القهقهـة،

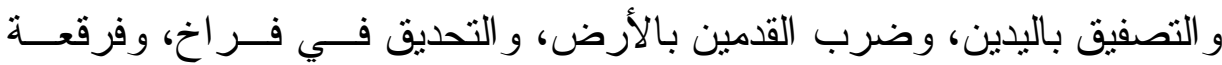

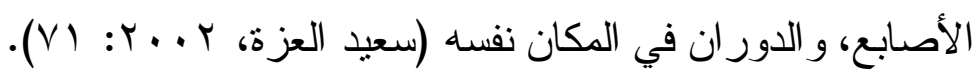

كما يبدي الطفل التوحدي سلوك التتمية الصوتي و الذي يتضمن الكلام غير

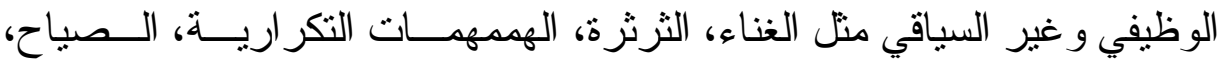

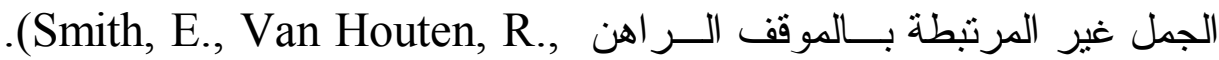
1996: 253)

وتتسبب السلوكيات التكر ارية و المقيدة صعوبات جمه للأطفال المـصابيين بإضطر اب طيف التوحد بسبب طبيعتها الثناذه و الصاخبه فهى تستهلك سـاعات يقظتهم، وتتداخل مع أنشتطهم الأسرية اليومية (Gordon, C., 2000:437). كما انها ترتبط بارتفاع معدلات الضغوط و الاضطر ابات النفـسية لــدى

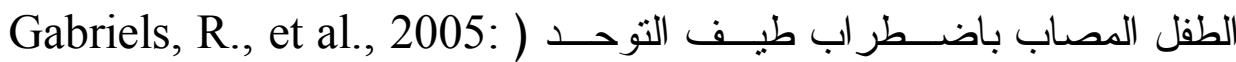

كما تؤدي هذه الافعال و الطقوس القهرية الــى قــصور فــي النــــاحي الإدر اكية و الانتباهية و المعرفية، كما انها تعيق دمج مضطربي طيف التوحد في الفي

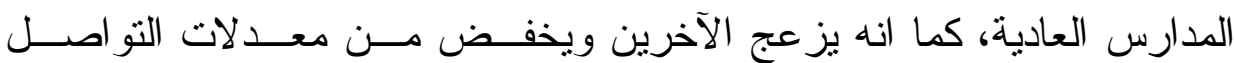
الاجتماعي (Loftin, R., et al., 2008: 1124). 


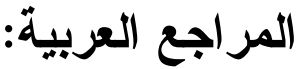

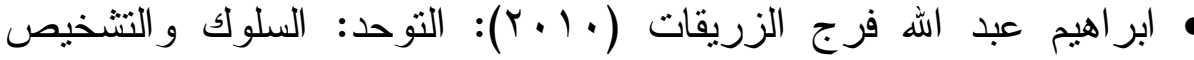
و العلاج، دار و ائل للنشر ، عمان.

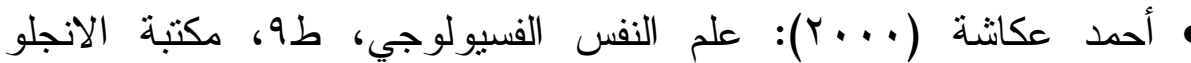

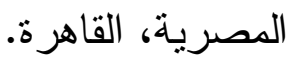

• أحمد عكاثة (r...r): الطب النفسي المعاصر، طا، مكتبة الانجلو

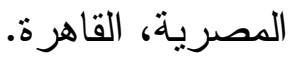

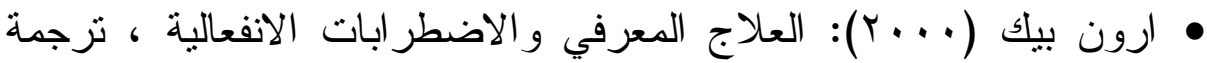
عادل مصطفى، دار الأفاق العربية، القاهرة. • أمال قطينة (r . . r): أمر اض النفس وعلاجها بالذكر، طا، دار الحامد للنشر و التوزيع، عمان.

• أنور الحمادي (10 ب): خلاصة الدليل التشخيصي والإحصائي الخامس للاضطر ابات العقلية DSM 5 طا، الدار العربية للعلوم، بيروت. • إيهاب محمد خليل (9 . ب): التوحد والإعاقة العقلية، مؤسسة طيبة،

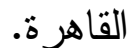

• حامد عبد السلام زهران ( (. ب)): الصحة النفسية و العلاج النفسي، ط؟،

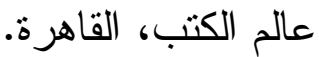

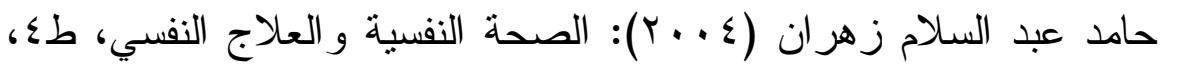
عالم الكتب للنشر و التوزيع، القاهرة. 


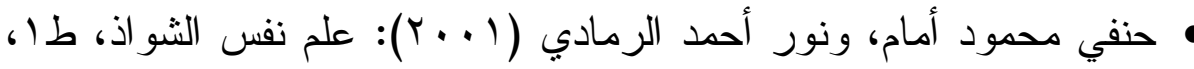
مكتبة الانجلو المصرية، القاهرة.

ديفيد بارلو ترجمة صفوت فرج، و آخرون (10 • ب): مرجع إكلينيكي في الاضطر ابات النفسية دليل علاجي تفصيلي، طب، مكتبة الانجلو مصرية،

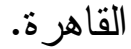

رمزية غريب (؟991): بحوث في علم النفس، الهيئة المعرفية العامة

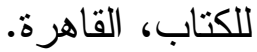

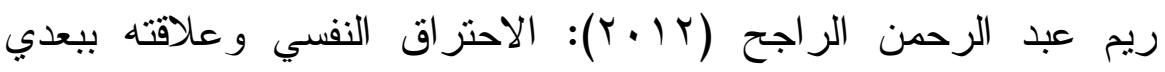

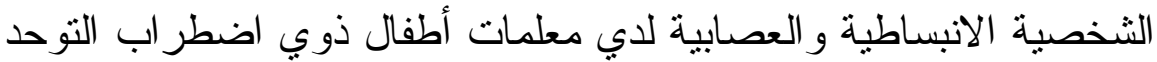
بمدينة الرياض، رسالة ماجستير غير منشورة، جامعة الملك سعود،

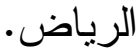
سايمون كو هين، وباتريك بولتون ( . . ץ): حقائق عن التوحد، ترجمة عبد اله حمدان، طا، أكاديمية التربية الخاصة، الرياض.

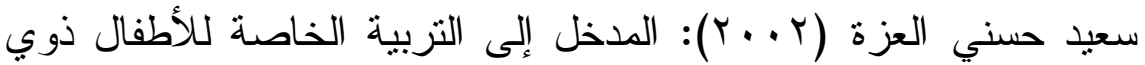
الحاجات الخاصة، الدار العلمية الدولية للنشر و التوزيع، عمان. • صباح السقا (عـا•ب): فاعلية العلاج الاسترافي- السلوكي للوسواس القهري، مجلة جامعة دمشق مج · با، عدد ( (1)، سوريا. عادل الرمادي (1 +. r): العلاج المعرفي السلوكي- أسس وتطبيقات، دار

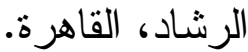




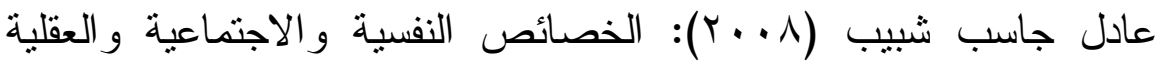
للأطفال المصابين بالنوحد من وجهة نظر الآباء، رسالة ماجستير غير

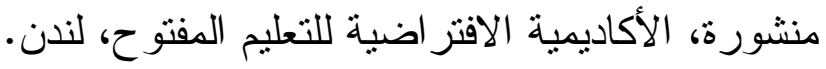

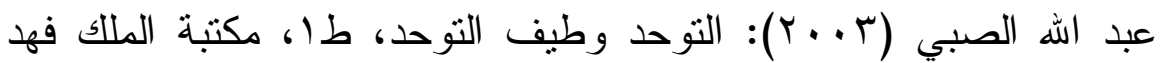

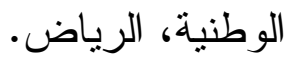
فضيلة الراوي، وآمال حماد (9991): التوحد: الإعاقة الغامضة، طا، الرياض

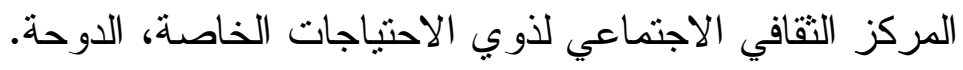

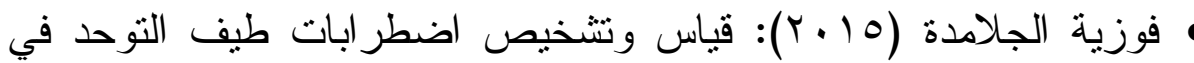
ضوء المعايير التتخيصية الواردة في (DSM-4/DSM-5)، دار المسيرة للنشر و الطباعة و التوزيع عمان.

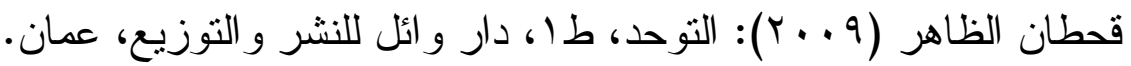

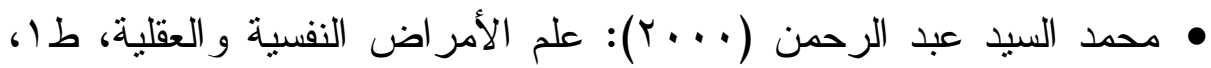
دار قباء للطباعة و النشر ، القاهرة. • محمد حسن غانم (ع . بץ): الوسواس القهري، المكتبة المصرية للطباعة

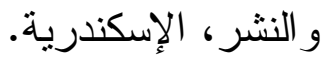
• محمود محمد إبر اهيم (10 • ب): البنية العالمية للمقياس العربي للوسواس القهري لدى طلبة جامعة السلطان قابوس، مجلة العلوم التزبوية، مسقط، عمان.

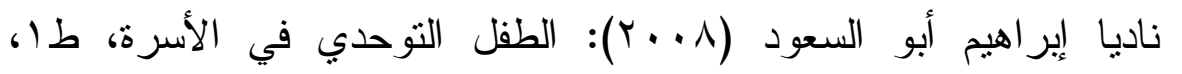
حورس الدولية للنشر و النوزيع، الإسكندرية. 


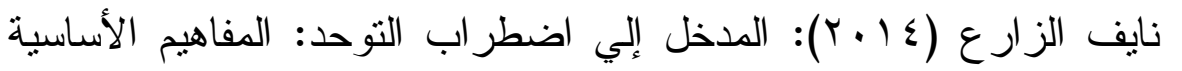
وطرق التذخل، دار الفكر ، عمان.

• نعيم الرفاعي (ra19): الصحة النفسية، دراسة في سيكولوجية التكيف، طا ، جامعة دمشق، سوريا.

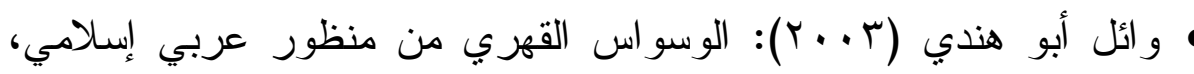
مطابع السياسة، الكويت.

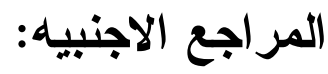

- Carr, E and D, M. (1985): Reducing behavioral problems through functional communication training, Journal of Applied Behavior Analysis, 18, PP. 111- 126.

- Wing, L. (1996): The autistic spectrum: A Guide for parents and professionals. Psychology Press. $2^{\text {nd }}$ Ed., PP.301- 312.

- Wakefield, A. (1998): IIeal-Lymphoid-nodular hyperplasia, non-specific colitis, and pervasive developmental disorder in children. Lancet, PP 351- 637.

- World Health Organization (1992): The ICD-10 Classification of Mental and Behavioral Disorders: Clinical descriptions and diagnostic guidelines. Geneva: World Health Organization., PP. 198-201.

المجلد السادس


- Bogdashina, O. (2006): Theory of mind and the triad of perspectives on autism and Asperger syndrome. London and Philadelphia: Jessica Kingsely Publisher., PP. 225274.

- Heward, L. (2003): Exceptional Children: An Introduction to Special Educational, $7^{\text {th }}$ ed. Merrill Prentice - Hall. Upper Saddle River, New Jersy, U.S.A., PP. 455- 516.

- Smith, D. (2001): Introduction to Special Education: Teaching in an age of opportunity. PP. 506- 517. Needham, MA: Allan and Bacon.

- Smith, E., \& Van Houten, R. (1996). A comparison of the characteristics of self-stimulatory behavior in normal children and children with developmental disabilities. Research in Developmental Disabilities, 17, 253-268.

- Greisberg, S. (2005). Neuropsychological functioning of children with obsessive-compulsive disorder. (upublished phD Thesis). DAI, pp. 265- 272.

- Gordon, C. (2000). Commentary: Considerations on the pharmacological treatment of compulsions and stereotypies with serotonin reuptake inhibitors in pervasive 
developmental disorders. Journal of Autism and Developmental Disorders, 30, 437-438.

- Gabriels, R. , Cuccaro, M. , Hill, D., Ivers, B. , \& Goldson, E. (2005).

- Repetitive behaviors in autism: relationships with associated clinical features. Research in Developmental Disabilities, 26(2), 169.

- Loftin,R., Odom,S.,\& Lantz, J.(2008). Social Interaction and Repetitive Motor Behaviors. J Autism Dev Disord, $38,1124-1135$.

- Pinard, Gumley, Athansios, Karatizas, Kevin, power, James, Reilly, Lisa, Acnay Margaret, (2004) Early intervention for relapse in schizophrenia ; impact of cognitive behavioral therapy on negative beliefs about psychosis and self esteem british Journal of clinical psychology, vol45, pp. 266- 269.

- Van der Linden, M., \& Ceschi, G. (2008). Traite de psychopathologie cognitive: Tome II- Etats psychopathologiques (Vol.2) Groupe de Boeck, pp. 119125. 
- O’Leary, E. (2005). Cognitive processing characteristics n obsessive compulsive disorder subtypes. University of Canterbury, pp. 20- 23.

- Myhr. G, Sookman. D. \& Pinard. G. (2004). Attachment Security and Parental Bonding in Adults witth Obsessive Compulsive Disorder: a Comparison with Depressed outPatients and Health Controls . Acta Psychaiatric Scandinavia, 109 (6), 447- 456. 